\section{The Schroeder Institute in Uzbekistan: Breeding and Germplasm Collections}

Mirmahsud M. Mirzaev and Uri M. Djavacynce

Richard R. Schroeder Uzbek Research Institute of Fruit Growing, Viticulture, and Wine Production, 700000 Tashkent, Glavpochta, ab \#16, Republic of Uzbekistan

\section{David E. Zaurov, ${ }^{1}$ Joseph C. Goffreda, Thomas J. Orton, ${ }^{2}$ Edward G. Remmers, and C. Reed Funk}

Department of Plant Biologyand Pathology, Cook College, Rutgers University, New Brunswick, NJ 08901-8520

Additional index words. germplasm, apples, walnuts, peach, grapes, plums, almonds, apricots, pistachios, breeding

Central Asia was largely isolated from the western world from the early 1800s until 1991, when the former Soviet Union was dissolved. During this time, many research institutions were established to work on economically important crop species and to amass large and unique germplasm collections, including the

Received for publication 3 Mar. 2003. Accepted for publication 17 Sept. 2003.

${ }^{1}$ To whom reprint requests should be addressed; e-mail zaurov@aesop.rutgers.edu.

${ }^{2}$ Department ofExtension Specialists, Rutgers Cooperative Extension, Rutgers Univ., New Brunswick, N.J.
Uzbek Scientific Research Institute of Plant Industry (former branch of VIR) and Uzbek Scientific Research Institute of Cotton Breeding and Seed Production.

The Turkestan Agricultural Experiment Station (TAES) was established in 1898 in Tashkent Province, Republic of Uzbekistan (Fig. 1). Academician Richard R. Schroeder (Fig. 2) served as the director of TAES from 1902 to 1944 . Initially, TAES focused on vegetables; fiber crops, such as cotton (Gossypium hirsutum L. and G. barbadense L.), kenaf (Hibiscus cannabinus L.), and hemp; tree fruits; grapes (Vitis vinifera L.); various
(Cannabis sativa L.), rice (Oryza sativa L.), cereal crops, and forage crops. Later, separate research institutes were established to focus on individual crops and initiate specific breeding programs. TAES was the first institute in Central Asia established for studies of genetics/breeding and the cultural management of fruits, grapes, and nuts.

Schroeder developed improved cultivars of cotton, rice, corn (Zea mays L.), and other crops (Schroeder, 1956). In tree fruits, he focused on improving cold-hardiness, resistance to diseases and insects, and yield. In 1911, Schroeder participated in the 7th International Congress of Arid Lands in the United States for cotton and orchard crops. While in the United States, he collected seeds of legumes, sorghum, and cotton cultivars and evaluated them in Central Asia. Shortly thereafter, Schroeder published an agricultural monograph that was widely distributed throughout the Russian Empire and, later, the USSR (Schroeder, 1913).

Following Richard Schroeder's death in 1944, his son, Alexander R. Schroeder, continued the apple (Malus $\times$ domestica Borkh.) breeding program, developing and releasing cultivars that are still popular in Central Asia: 'Renet Tashkentsky', 'Borovinka Tashkentskay', 'Tilly alma', 'Letnee polosatoe', 'Iskander', 'Ubileinoe Shredera', 'Navoi', 'Dastarhoni', 'Argus', 'Kalvil Tashkentsky', and 'Zimnee Shredera'. Later, Schroeder's granddaughter, Elena Schroeder, joined the

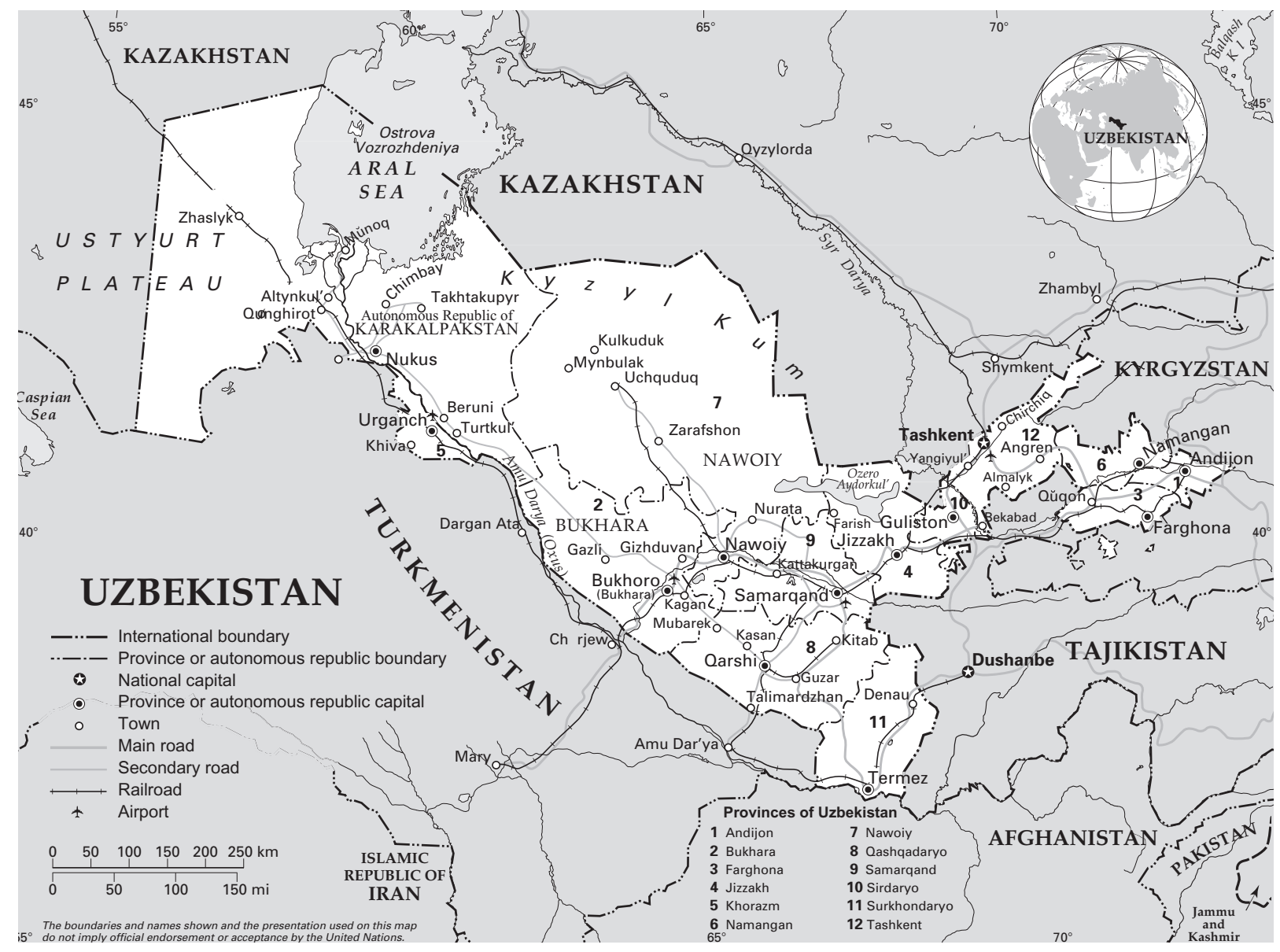

Fig. 1. Map of the Republic of Uzbekistan (reproduced with permission from the Dept. of Public Information, Cartographic Section, United Nations, Map No. 3777 Rev. 3, Aug. 1998). 


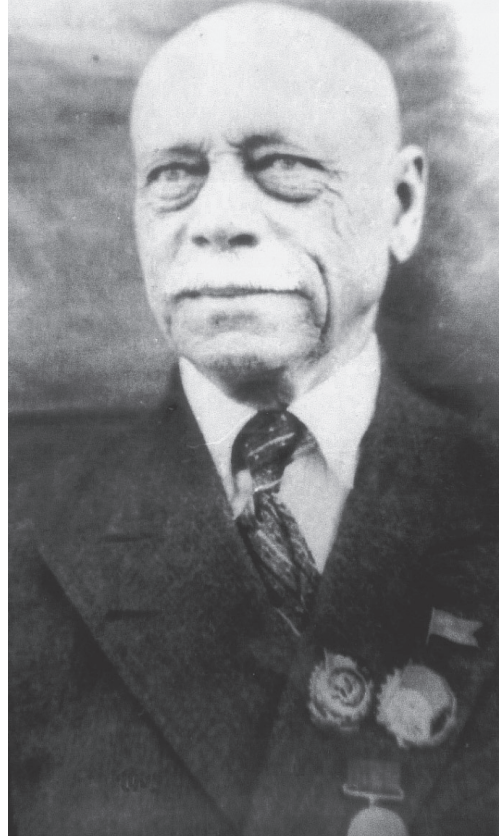

Fig. 2. Academician Richard R. Schroeder served as director of the Institute from 1902 to 1944.

apple breeding program, and presently continues this work.

TAES was named after Richard Schroeder in 1929. At this time, the scientific program was expanded and awarded greater financial support by the federal government. In 1947 the organization was renamed the Richard R. Schroeder Uzbek Research Institute of Fruit Growing, Viticulture, and Wine Production (referred to hereinafter as the Schroeder Institute).

Mahmud M. Mirzaev (Fig. 3) was appointed director of the Schroeder Institute in 1949 and served in this role for 51 years until his death in Aug. 2000. He focused on the interspecific hybridization of orchard species and development of improved grape cultivars. Mirzaev published over 300 scientific articles, books, and monographs, including Apricots in Uzbekistan (Mirzaev and Kkuznecov, 1984), Ampelography of Uzbekistan (Mirzaev et al., 1984), Pomology of Uzbekistan (Mirzaev et al., 1983), Orchards of the Foothills and Mountain Zone of Uzbekistan (Mirzaev, 1982), and Vineyards of the Foothills and Mountain Zone of Uzbekistan (Mirzaev, 1980). In recognition of his voluminous contributions, Mirzaev was elected to both the Uzbek and Russian Academies of Science. His son, Mirmahsud M. Mirzaev, replaced him as Institute director.

From 1956 to 1957 , branches of the Schroeder Institute were established in geographical areas of Uzbekistan having different soil types and climatic conditions. The Schroeder Institute currently has five major satellite facilities: a branch in Samarqand Province devoted to orchard and vineyard crops, a branch in Farghona Province devoted to orchard and vineyard crops in mountainous regions, the South Uzbekistan Experiment Station in Surkhondaryo Province, and two branches in Tashkent Province, one specializing in wine production and the other in orchard crops. There are also three minor satellite branches:

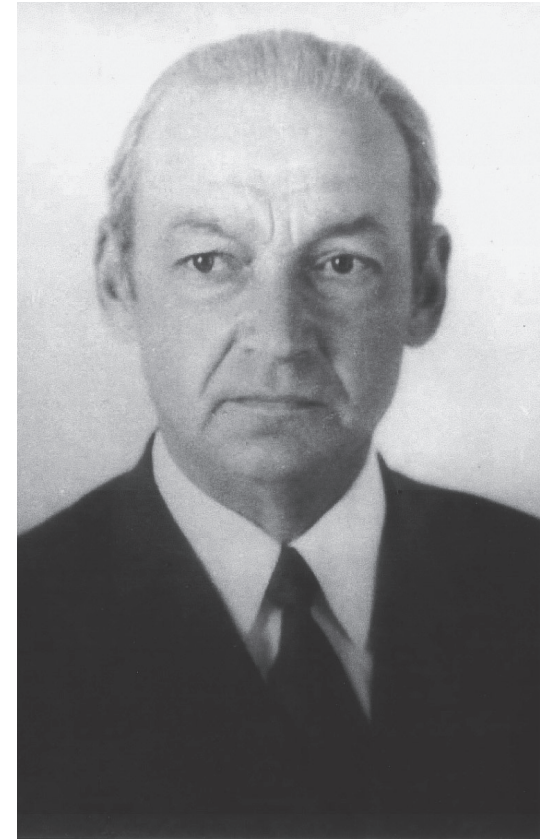

Fig. 3. Academician Mahmud M. Mirzaev served as director of the Institute from 1949 to 2000.

Namangansky (Namangan Province), Sokhsky (Andijon Province), Bukharsky (Bukhara Province), and 17 experimental farms (Fig. 1). In total, the Schroeder Institute oversees 11,000 ha of research farms.

The Institute also developed an educational program where students could earn associate degrees in orchard crops. In the late 1960s, the Schroeder Institute created a Bureau of Agricultural Machinery to develop or adapt farm equipment for use in orchards. In addition, the Institute developed new cultivars of fruit, nut, citrus, and grapes, and developed cultural and processing technology, including the canning, packaging, and bottling of fruit juices, wines, champagnes, vodkas, and cognac. The Institute currently operates a full-scale wine production plant with adequate storage facilities for aging studies. Furthermore, the Schroeder Institute established an agribusiness college in 1995 .

The main Schroeder Institute in Tashkent Province includes 22 laboratories and greenhouses that are used for research in plant breeding, cultural management, mechanization, and physiology and biochemistry of crops. About 300 faculty and technicians are employed at the main facility. The Institute maintains an extensive and unique field gene bank of more than 2000 advanced accessions of apples and pears, about 1300 grapes, 260 citrus, 500 apricots (Prunus armeniaca L.), 270 peaches (Prunus persica L. Batsch.), 65 plums (Prunus domestica L.), 125 brambles, and 150 nuts $\{$ walnuts (Juglans regia L.), almonds [Prunus dulcis (Mill.) D.A. Webb.], and hazelnuts (Corylus avellana L.) \}. The Institute also has collections of dates (Zizyphus jujuba Mill.), figs (Ficus carica L.), persimmons (Diospyrus kaki L.), pomegranates (Punica granatum L.), and other fruits (Esenbaev et al., 1981).

The Institute has developed and released 150 cultivars of fruits, berries, and grapes. In addition, 58 advanced selections are nearing release. Cultivars developed by the Schroeder Institute have been widely accepted by Uzbek commercial growers: $80 \%$ of the apples, $60 \%$ of the pears, $69 \%$ of the grapes, $90 \%$ of the strawberries (Fragaria xananassa L.), 65\% of the quince (Pyrus cydonia L.), 65\% of the peaches, $90 \%$ of the black currants (Ribes nigrum L.), and $90 \%$ of the nuts in Uzbekistan are cultivars released by the Institute. Some are widely grown throughout the former USSR.

The present goals of the Institute include the following.

1. Develop new cultivars of orchard crops and grapes that produce high yields of fruit with improved quality under various climatic extremes, and also exhibit disease and insect resistance, cold-hardiness, and drought tolerance.

2. Develop cultivars for use on extremely poor soils (sandy, stony, salty, and/or dry soils).

3. Improve drying technology and storage methods for fruits and grapes (i.e., raisins).

4. Develop new farm machinery for orchards and vineyards.

Fig. 4. Apricot 'Ubileini Navoi'.

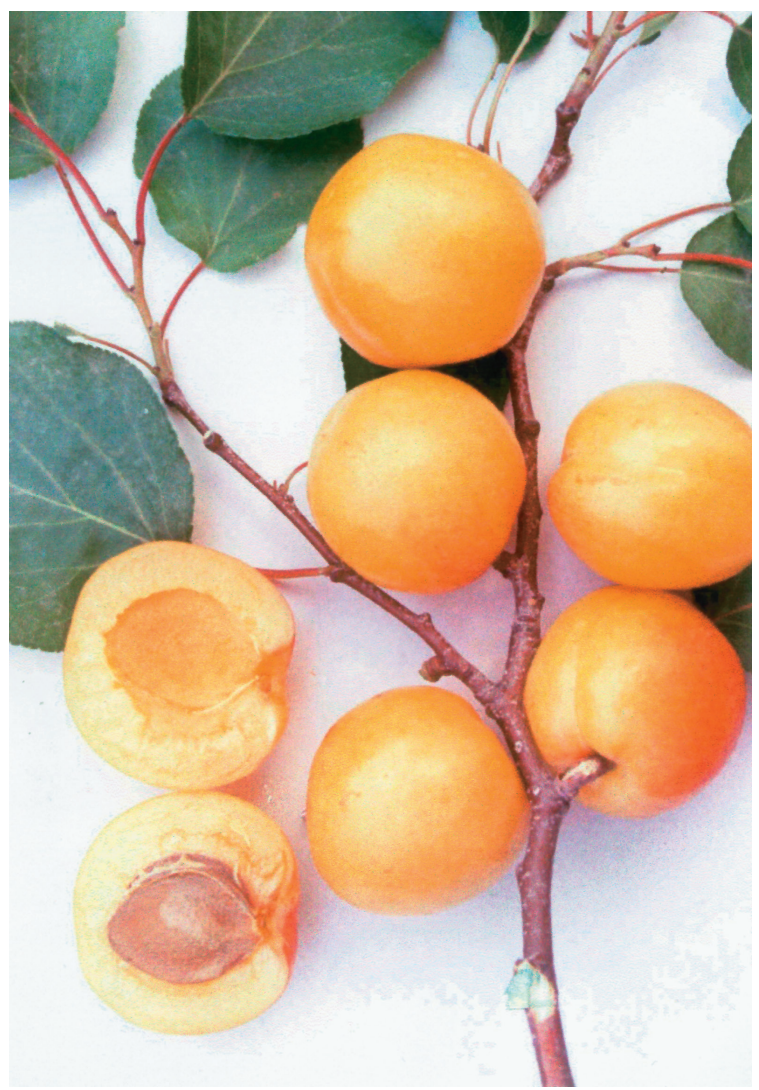


Breeding Strategies Used at the Schroeder Institute

Apricots. In 1930, a systematic and comprehensive breeding program was initiated. Initial evaluations identified three cultivars, 'Kursadik', 'Arzami', 'Ruhi djuvanon', and two European cultivars, 'Krasnoshoki' and 'Korolevski', as resistant to the widely fluctuating climatic conditions common in Uzbekistan, especially flower and fruit damage due to late spring frosts breeders developed new apricot cultivars with late flowering and high fruit quality by selecting from hybrids between local landraces and European cultivars. Six frost-tolerant cultivars were developed and released: 'Samarqandski ranni', 'Medovi', 'Uzbekistansky', 'Ubileini Navoi' (Fig. 4; Table 1), 'Samarqandski \# (Kovalev, 1963). Schroeder Institute plant

117', and 'Zarafshansky pozdni' (Mirzaev and Kuznecov, 1984; Mirzaev et al., 1983). The cultivar 'Ubeleini Navoi', which originated from a cross between 'Arzami' and 'Falgarsky gulungi', has a reputation for high fruit quality and yield.

The first cultivars that were developed displayed flower bud resistance to cold, but did not produce consistently acceptable crop yields. Later, scientists developed new, late-blooming apricot cultivars, including 'Gulistan', 'Navruz', 'Avicena', 'Zarafshansky pozdnii' (Table 1), 'Abadi', 'Nuravshon', and 'Mohir' (Mirzaev, 2000; Mirzaev and Kuznecov, 1984; Turakulov, 1993), that had a higher chilling requirement and were later blooming than the previous cultivars. They had, concomitantly, greater resistance to frost and consistently good fruit yields. The first bloom is at least 1 week

Table 1. Characteristics of late flowering and/or frost-tolerant apricots.

\begin{tabular}{|c|c|c|c|c|c|c|}
\hline Cultivar & $\begin{array}{c}\text { Avg fruit } \\
\text { wt (g) }\end{array}$ & Fruit color & $\begin{array}{l}\text { Years to fruit } \\
\text { production }\end{array}$ & $\begin{array}{c}\text { Yield } \\
\left(\mathrm{t} \cdot \mathrm{ha}^{-1}\right)\end{array}$ & $\begin{array}{l}\text { Ripening } \\
\text { time }\end{array}$ & $\begin{array}{l}\text { Major } \\
\text { end use }\end{array}$ \\
\hline Gulistan & 33 & $\begin{array}{l}\text { Bright golden } \\
\text { with ruddiness }\end{array}$ & 4 & 10 & Early June & Dried apricots \\
\hline Navruz & 40 & $\begin{array}{l}\text { Partly yellow, } \\
\text { with dark red skin }\end{array}$ & 5 & 10 & Early July & $\begin{array}{l}\text { Fresh and } \\
\text { canned }\end{array}$ \\
\hline Avicena & 45 & Light pink & 5 & 10 & $\begin{array}{l}\text { Late June/ } \\
\text { early July }\end{array}$ & $\begin{array}{l}\text { Dried, fresh, } \\
\text { and canned }\end{array}$ \\
\hline Zarafshansky pozdnii & 40 & $\begin{array}{l}\text { Yellow with } \\
\text { small dark streaks }\end{array}$ & $5-6$ & 13 & Late July & Dried \\
\hline Ubileini Navoi & 45 & $\begin{array}{l}\text { Gold-yellow } \\
\text { with large } \\
\text { bright streaks }\end{array}$ & 4 & 14 & $\begin{array}{l}\text { Late June/ } \\
\text { early July }\end{array}$ & $\begin{array}{l}\text { Fresh, canned, } \\
\text { and dried }\end{array}$ \\
\hline
\end{tabular}

Table 2. Characteristics of selected peach and nectarine cultivars.

\begin{tabular}{|c|c|c|c|c|c|}
\hline Cultivar & $\begin{array}{l}\text { Avg fruit } \\
\text { wt (g) }\end{array}$ & Fruit color & $\begin{array}{l}\text { Years to fruit } \\
\text { production }\end{array}$ & $\begin{array}{c}\text { Yield } \\
\text { (kg/tree) }\end{array}$ & $\begin{array}{l}\text { Ripening } \\
\text { time }\end{array}$ \\
\hline Malinovi & Up to 300 & $\begin{array}{l}\text { White with } \\
\text { pink streaks }\end{array}$ & $5-6$ years & $60-80$ & August \\
\hline Nectarin jelti & 70 & Light yellow & $\begin{array}{l}2-3, \text { full } \\
\text { in } 5 \text { years }\end{array}$ & 120 & Late August \\
\hline Podarok Uzbekistana & 160 & Golden yellow & 3 & 120 & $\begin{array}{l}\text { Late July/ } \\
\text { early August }\end{array}$ \\
\hline Farhad & Up to 400 & Dark yellow & 3 & 130 & September \\
\hline $\begin{array}{l}\text { Shirin magiz } \\
\text { (saucer shape) }\end{array}$ & Up to 150 & $\begin{array}{l}\text { Orange with } \\
\text { pink streaks }\end{array}$ & 3 & $130-140$ & July \\
\hline Nectarin tashkentsky & 65 & Orange & 5 & 115 & Mid-July \\
\hline
\end{tabular}

Table 3. Characteristics of selected apple cultivars.

\begin{tabular}{|c|c|c|c|c|c|c|c|}
\hline Cultivar & $\begin{array}{l}\text { Avg fruit } \\
\text { wt }(g)\end{array}$ & Fruit color & $\begin{array}{l}\text { Years to fruit } \\
\text { production }\end{array}$ & $\begin{array}{l}\text { Yield } \\
\left(\mathrm{t} \cdot \mathrm{ha}^{-1}\right)\end{array}$ & $\begin{array}{l}\text { Ripening } \\
\text { time }\end{array}$ & $\begin{array}{l}\text { Major } \\
\text { end use }\end{array}$ & Flavor \\
\hline Afrosiabi & $100-150$ & $\begin{array}{l}\text { Golden-yellow } \\
\text { with streaks } \\
\text { of orange-red }\end{array}$ & $4-5$ & $15-17$ & 1-10 July & Fresh & $\begin{array}{l}\text { Acid-sweet } \\
\text { with pleasant } \\
\text { aroma }\end{array}$ \\
\hline $\begin{array}{l}\text { Borovinka } \\
\text { Tashkentskay }\end{array}$ & 140 & $\begin{array}{l}\text { Greenish-yellow } \\
\text { with dark } \\
\text { pink stripes }\end{array}$ & $4-5$ & $16-18$ & 10-20 July & Fresh & Acid-sweet \\
\hline Nafis & $160-180$ & $\begin{array}{l}\text { Greenish-yellow } \\
\text { with slight } \\
\text { pink patches }\end{array}$ & v & $20-22$ & $\begin{array}{l}\text { Early } \\
\text { October }\end{array}$ & Fresh & Sweet \\
\hline $\begin{array}{l}\text { Pervenece } \\
\text { Samarqandat }\end{array}$ & 90 & Golden-yellow & $3-4$ & $15-17$ & Early June & Fresh & Acid-sweet \\
\hline Saratoni & $120-150$ & $\begin{array}{l}\text { Light green } \\
\text { with slight } \\
\text { red flecks }\end{array}$ & $4-5$ & $14-16$ & 1-10 July & Fresh & $\begin{array}{l}\text { Acid-sweet } \\
\text { with aroma }\end{array}$ \\
\hline Hasildar & $150-200$ & $\begin{array}{l}\text { Light green with } \\
\text { yellow shade }\end{array}$ & $2-3$ & $18-20$ & 1-10 June & Fresh & Acid-sweet \\
\hline
\end{tabular}

later than the 'Ubelini novai' and 'Kursadik' cultivars (Mirzaev, 2000).

Peaches and nectarines. The peach-breeding program focused on the improvement of cold-hardiness and consistent yields. Using parents from various geographical regions, the first releases were developed via recurrent hybridization and selection. Although improved in cold hardiness and yield consistency, they lacked fruit quality, postharvest life, and fruit uniformity needed for canning.

Later cultivars with improved disease resistance $\{$ leaf curl [Taphrina deformans (Berk.) Tul.] and powdery mildew (Sphaerotheca pannosa Lev.f. persicae Woroich.)\}, cold hardiness, and high fruit quality were developed (Cherevachenko, 1960). The primary focus was on yellow-fleshed freestone cultivars. Characteristics of selected peach cultivars are shown in Table 2. Fruit of these cultivars were used in a variety of ways, for example, as fresh, dried, and canned. The Schroeder Institute has developed and released more than 70 new peach and nectarine hybrids having high fruit quality (Mirzaev, 1993).

Apples. The main objective of the applebreeding program has been to develop improved resistance to cold temperatures during the spring, fall, and winter, and to high summer temperatures. The overall goal is the year-round availability of high quality table apples using a combination of early-, mid-, and late-maturing cultivars.

The apple-breeding program was started by hybridizing local cultivars and landraces resistant to cold temperatures with cultivars from throughout the world. Subsequently, crosses and backcrosses were made with the progeny of the initial hybrids and cultivars displaying the desired characteristics. Breeders used mixed pollen from U.S. and European cultivars to produce the hybrids with the assumption that selection pressure (e.g., low temperature) applied to a heterogeneous population of pollen will lead to more desirable fertilization events and subsequent hybrid plants. Openpollinated progeny from these hybrids were then subjected to selection. As a result, 29 cultivars were released. The characteristics of the most notable apples are shown in Table 3 (Schroeder, 1993).

Pears. The primary objectives of the pearbreeding program have been summer heat tolerance, drought resistance, and high fruit quality. In the early 1940s, crosses were made among cultivars from several geographical regions representing widely divergent climatic zones. Individual trees displaying the best overall performance were selected and intercrossed, followed by further selection. The characteristics of the most notable Uzbek cultivars developed in this program are described (Table 4), Mirzaev at al. (1983).

Grapes. Uzbekistan is among the oldest grape-growing regions in the world. The best known grapes of Uzbekistan are cultivars used both as fresh table grapes and for dried raisins. The diversity of table grape/raisin cultivars maintained at the Schroeder Institute is considered to be among the highest of comparable organizations worldwide, the 
Table 4. Characteristics of selected pear cultivars.

\begin{tabular}{|c|c|c|c|c|c|c|}
\hline Cultivar & $\begin{array}{l}\text { Avg fruit } \\
\text { wt }(g)\end{array}$ & Fruit color & $\begin{array}{l}\text { Years to fruit } \\
\text { production }\end{array}$ & $\begin{array}{l}\text { Yield } \\
\left(\mathrm{t} \cdot \mathrm{ha}^{-1}\right)\end{array}$ & $\begin{array}{l}\text { Ripening } \\
\text { time }\end{array}$ & $\begin{array}{l}\text { Major } \\
\text { end use }\end{array}$ \\
\hline Podarok & $150-170$ & $\begin{array}{l}\text { Light yellow } \\
\text { with red blush }\end{array}$ & 4 & 17 & 10-20 Aug. & $\begin{array}{l}\text { Fresh, dried, } \\
\text { and canned }\end{array}$ \\
\hline Rano & 170 & Light yellow & $5-6$ & $17-18$ & September & Fresh and dried \\
\hline $\begin{array}{l}\text { Zimnay } \\
\text { (Nashvati-2) }\end{array}$ & $200-350$ & $\begin{array}{l}\text { Light green } \\
\text { with ruddiness }\end{array}$ & 4 & 18 & $1-15$ Oct. & $\begin{array}{l}\text { Fresh, with } \\
\text { shelf life } \\
\text { until } 15 \text { Mar. }\end{array}$ \\
\hline Kulyly & $400-1000$ & Light green & $4-5$ & $16-18$ & $1-15$ Oct. & Fresh \\
\hline Sari guzal & $230-265$ & $\begin{array}{l}\text { Light green } \\
\text { with yellow sh }\end{array}$ & hade ${ }^{4}$ & 17 & 1-20 July & Fresh \\
\hline
\end{tabular}

Table 5. Characteristics of selected grape cultivars.

\begin{tabular}{|c|c|c|c|c|c|c|c|c|}
\hline Cultivar & $\begin{array}{c}\text { Avg fruit } \\
\text { wt (g) }\end{array}$ & $\begin{array}{c}\text { Avg cluster } \\
\text { wt (g) }\end{array}$ & $\begin{array}{l}\text { Time of } \\
\text { ripening }\end{array}$ & $\begin{array}{c}\text { Soluble } \\
\text { solids (\%) }\end{array}$ & Fruit color & $\begin{array}{l}\text { Yield } \\
\left(\mathrm{t} \cdot \mathrm{ha}^{-1}\right)\end{array}$ & $\begin{array}{l}\text { Major } \\
\text { end use }\end{array}$ & $\begin{array}{l}\text { Seeded/ } \\
\text { seedless }\end{array}$ \\
\hline Ranni Shredera & 4.5 & $350-400$ & July-August & $18-20$ & Light violet & $14-16$ & Fresh & Seeded \\
\hline Rizamat & $5+$ & $300-350$ & 15 Aug. & 20 & Pink & $15-18$ & Fresh, dried, canned & Seeded \\
\hline Kishmish Zarafshan & $5-6$ & $350-400$ & 20-30 Aug. & $20-24$ & Light green & $14-16$ & Fresh, dried & Seedless \\
\hline Kishmish Samarqand & 3.5 & $200-230$ & 10-20 Aug. & $19-20$ & Light green & $12-14$ & Fresh, dried & Seedless \\
\hline Ertapishar & 2.5 & 220 & Early July & $15-16$ & Dark pink & $8-10$ & Fresh & Seeded \\
\hline Kishmish Terakli & 2.5 & 250 & Late August & $25-27$ & Black & $14-15$ & Fresh, dried & Seedless \\
\hline Kishmish Duoba & 4 & $300-350$ & Mid-August & $22-24$ & Dark blue & $15-17$ & Fresh & Seedless \\
\hline Husaine muskatni & 7 & 500 & Mid-August & $20-22$ & Light green & $16-18$ & Fresh, dried & Seeded \\
\hline
\end{tabular}

number totaling $>1300$ advanced accessions (Esenbaev et al., 1981).

The main goals of the Institute's grape breeding program have been to improve fruit and fruit cluster quality and genetic resistance to diseases and insect pests. The ideal table grape cultivar is characterized by large fruit clusters comprising large seedless individual fruit (Smirnov, 1985).). Since 1986, breeders at the Institute have developed and released more than 20 new cultivars (Djavacynce, 2001). The characteristics of the most important cultivars are described in Table 5 (Mirzaev et al., 1984). A photograph of the seedless grape 'Kishmish Zarafshan' is shown in Fig. 5.

Cherries, plums, strawberries, European black currants, and Chinese dates. The Schroeder Institute also developed many new cultivars of cherry (Prunus avium L. 'Bahor'); plum ('Chernosliv Samarqandski'); strawberry ('Uzbekistanskay', 'Pamyt Shredera', and 'Krasavica Uzbekistana'); European black currants ('Plotnomyasnay', 'Kishmishnay', and 'Dustlik'); and Chinese dates (Melkoplodnii kislii \#1', 'Krupnoplodnii \#1', 'Ubilenii', and 'Dargomsky') (Mirzaev at al., 1983).

Nut species. Kalmikov (1968) reports that there are five major species of nuts grown on 32,000 ha in Uzbekistan. Of this, $84 \%$ consists of harvests in wild forests, and $16 \%$ is cultivated.

Pistachios (Pistacia vera L.). Pistachios represent the largest nut crop in Uzbekistan and are harvested mostly from the wild. The total area is $\approx 25,000$ ha, mostly concentrated in Surkhondaryo Province. The average yield is 0.5 to $1.5 \mathrm{~kg} /$ tree. Breeders located at the Institute's Bostandik Branch have developed more than 30 cold-hardy cultivars (Kalmikov, 1968).

Walnuts. Walnut is the second largest nut crop in Uzbekistan. The total area of walnut production is 4500 ha (400,000 trees), of which $89 \%$ are in Tashkent Province, $5 \%$ in Surkhondaryo, $4 \%$ in Samarqand, and 2\% in Farghona and Andijon Provinces. Wild trees yield $\approx 10 \mathrm{~kg} /$ tree, while cultivated trees yield in the range of 100 to $500 \mathrm{~kg} /$ tree, resulting in an average yield of 2.0 to $2.5 \mathrm{t} \cdot \mathrm{ha}^{-1}$. Walnut breeding research facilities are located at Institute branches in Tashkent (Bostandik) and Samarqand (Kalmikov, 1968).

Breeders at the Institute's Bostandik branch have developed or selected the following walnut cultivars: 'Bostandiksky', 'Rodina', 'Gvardeisky', 'Tenkoskorlupnii' (Fig. 6), 'Ideal', 'Uzbeksky kruponoplodii', 'Kazahstansky', and 'Panfilovece'. The above cultivars have high nut quality, high yield, precocious fruit maturation, resistance to diseases and insects, and cold hardiness (Kalmikov, 1968).

Almonds. Cultivated almonds are grown mostly in the Tashkent and Surkhondaryo provinces and are harvested from the wild in the Samarqand and Surkhondaryo provinces. The total land area of almonds in Uzbekistan is more than 2500 ha, $\approx 1000$ ha of which is cultivated. The best trees have a yield of 20 to $30 \mathrm{~kg} /$ tree of dried nuts (Kalmikov, 1968).

Breeders at the Bostandik branch of the Institute developed new genetic lines using hybridization followed by selection, primarily for spring frost tolerance. To date, they have released 11 new almond cultivars. The most widely grown cultivars are 'Pervenece', 'Kolhoznii', 'Rannii', 'Tyn-Shansky', 'Sablevidnii', 'Kosmichesky', 'Ugamsky', and 'Krasivii'. These cultivars feature cold hardiness, frost resistance, and resistance to fungal diseases.

Pecans (Carya illinoinensis Nutt). Pecans were introduced into Uzbekistan in 1934. Institute breeders have developed new pecan cultivars with superior qualities, specifically with $60 \%$ to $66 \%$ nut oil content. The best of these cultivars are 'Urojainii', 'Uzbekistan', and 'Pamyt Shroedera'. However, pecans are not currently widely grown in Uzbekistan (Kalmikov, 1968).
Hazelnuts. The European hazelnut was introduced in the mid 1800s and, like pecans, hazelnuts are not yet widely grown in Uzbekistan. Breeders located at the Institute's Bostandik branch have selected clones from the best accessions introduced from the Caucasus region (Kalmikov, 1968).

\section{Conclusions}

The objectives of many breeding programs to develop larger, higher yielding, and better storing fruit and nut crops have dramatically narrowed the genetic base of these species. The vast genetic diversity that has been collected and maintained at the Schroeder Institute in Uzbekistan is a valuable resource for fruit and

Fig. 5. Seedless grape 'Kishmish Zarafshan'.

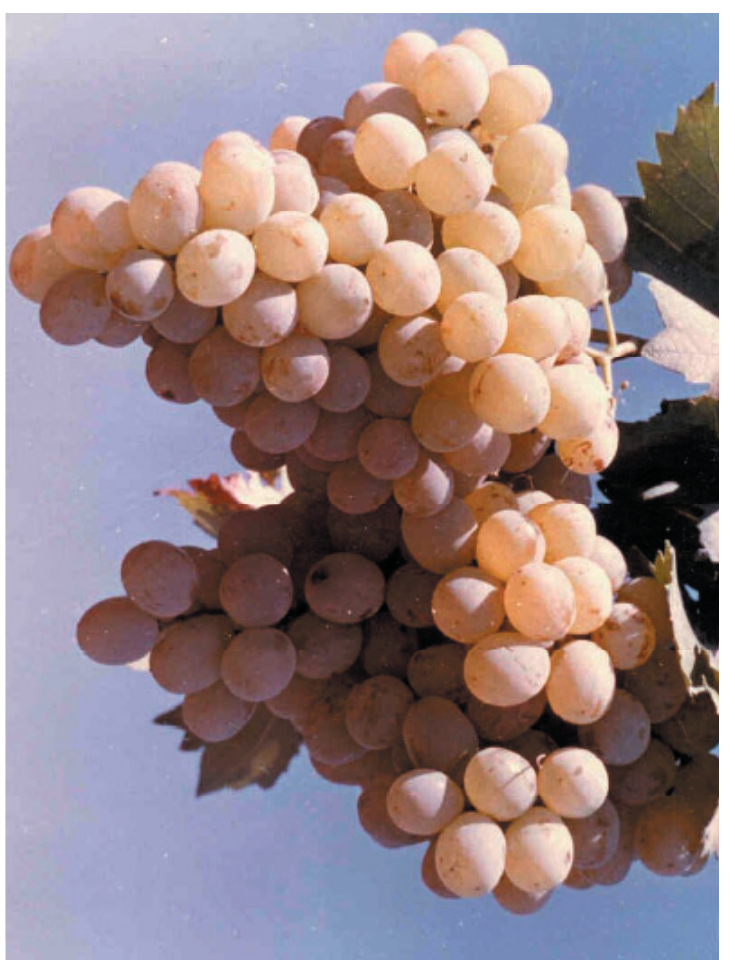



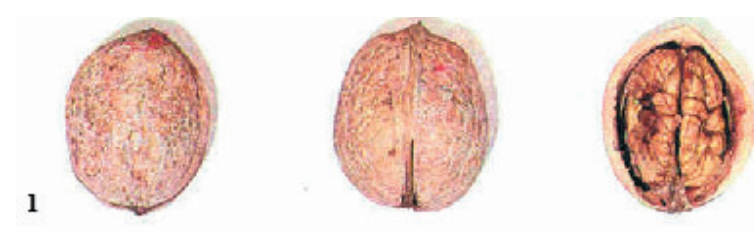

velop breeding lines and finished cultivar releases with increased disease resistance, cold-hardiness, and high quality. These cultivars, as well as the other genetic resources maintained at the Schroeder Institute, will be useful to develop novel genotypes with even greater tolerance to biotic and abiotic stresses in the future. Scientists interested in gaining access to these genetic resources should contact the Schroeder Institute.

\section{Literature Cited}

Cherevachenko, A.S. 1960. The best peach cultivars for Uzbekistan, p. 17-22. In: M. Mirzaev (ed.). New
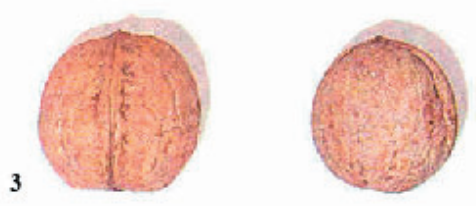

.Fig. 6. Walnut cultivars: 1) 'Bostonliksky pozdnocvetushii', 2) 'Uzbeksky skoroplodnii', and 3) 'Tonkoskorlupnii'.

nut breeding programs worldwide. The fruit breeding programs at the Schroeder Institute have used local cultivars, landraces, and at times, U.S. and European cultivars, to de-

of Uzbekistan (in Russian). Fan.

Tashkent.

Uzbekistan (monogr.; in Russian). Shark. Tashkent.

Esenbaev, Z.I., R.A. Safarov, N.G. Gaibov, M.M. Mirzaev, and M.M.Penson. 1981. Orchards of Uzbekistan (in Uzbek, Russian, and English). Uzbekistan. Tashkent.

Kalmikov, S.S. 1968. Nut species in Uzbekistan (in Russian). J. Sadovodstvo 10:26-28.

Kovalev, N.V. 1963. Apricots (in Russian). Kolos, Moscow.

Mirzaev, M.M. 1980. Vineyards of the foothills and mountain zone of Uzbekistan (in Russian).
Mirzaev, M.M. 1982. Orchards of the foothills and mountain zone of Uzbekistan (in Russian). Fan. Tashkent.

Mirzaev, M.M. and V.V. Kuznecov. 1984. Apricots in Uzbekistan (in Russian). Fan. Tashkent.

Mirzaev, M.M, V.V. Kuznecov, R.G. Borozdin, A.I. Frolov, S.M. Jivotinskay, A.H. Tabanali, and U. M. Djavacynce. 1983. Pomology of Uzbekistan. Uzbekistan (in Russian). Tashkent.

Mirzaev, M.M., A.H. Tabanali, A.I. Frolov, U.M. Djavacynce, K.K. Smirnov, G.I. Haidarkulov, A.G. Tibeikina, G.V. Ochienko, V.A. Arzumanov, and M.S. Juravel. 1984. Ampelography of Uzbekistan (in Russian). Uzbekistan. Tashkent.

Mirzaev, T.T. 1993. Conclusions of peach breeding, p. 74-77. In: M.M. Mirzaev (ed.). Breeding fruit and grapes in Uzbekistan (in Russian). Mehant. Tashkent.

Mirzaev, M.M. 2000. Apricots in Uzbekistan (in Russian). Shark. Tashkent.

Schroeder, R.R. 1913. Notes on the agriculture of the United States of America. Kancelyariya Turkestanskogo General Gubernatora (in Russian). Office of the Governor of Turkestan. Tashkent.

Djavacynce, U.M. 2001. Grapes of Fan. Tashkent.
Schroeder, E.A. 1993. Chapter on results of apple breeding in Uzbekistan, p. 28-42. In: M.M. Mirzaev (ed.). Breeding fruit and grapes in Uzbekistan (in Russian). Mehant, Tashkent.

Schroeder, R.R. 1956. Vol. 1. (from his collection of papers; in Russian). Fan. Tashkent.

Smirnov, K.V. 1985. Breeding seedless grapes, p. 57-64. In: M.M. Mirzaev (ed.). Breeding fruit and grape species (in Russian). Fan. Tashkent.

Turakulov, Z.T. 1993. Apricot breeding, p. 10-22. In: M.M. Mirzaev (ed.). Breeding fruit and grapes in Uzbekistan (in Russian). Mehant. Tashkent. 